\title{
Taxonomic analysis of flora diversity in Daursky Biosphere reserve
}

\author{
Lyudmila Saraeva ${ }^{1,2^{*}}$ \\ ${ }^{1}$ Daursky State Nature Biosphere Reserve, 674480 Nizhniy Tsasuchey, Zabaikalsky Krai, Russia \\ ${ }^{2}$ Central Siberian Botanical Garden SB RAS, 630090 Novosibirsk, Russia
}

\begin{abstract}
The article presents a taxonomic analysis of the Daursky reserve's flora. 634 species and subspecies of vascular plants (including 608 aboriginal and 30 adventive) have been identified, they belong to 290 genera and 74 families. The leading families amount to 476 species of aboriginal flora (75\% of total number) and 149 genera $(23 \%)$. The taxonomic spectre is headed by the families Asteraceae, Poaceae, Fabaceae, Rosaceae, Cyperaceae. The most part of the species are of the genera Carex, Artemisia, Potentilla. The adventives flora includes 30 species from 22 genera and 15 families or $5 \%$ of the reserve's flora composition. The largest number of species is registered in the families Chenopodiaceae and Poaceae. In the flora of the Daursky reserve 28 species of vascular plants are identified that are listed on the Red Books of the Russian Federation and Zabaikalsky krai. The area of the Daursky reserve ( $2 \%$ of the territory of Zabaikalsky krai) has a high level of biological diversity (it conserves $37 \%$ of the flora richness of Zabaikalsky krai), representativeness, special nature-protecting value and significance.
\end{abstract}

\section{Introduction}

The Daursky reserve is located in the south of Zabaikalsky krai (2\% of the territory of Zabaikalsky krai), at the border on Mongolia. The area of the reserve is 84,100 ha and of the surrounding buffer zone - 173,201 ha (Fig.1). The Daursky reserve was founded in 1987 with the aim of conservation and restoration in natural state of the steppe, forest-steppe, lake-steppe and wetland complexes of South-East Transbaikalia.

The relief is generally from plain to tumulose, absolute heights of the area are 600 to $800 \mathrm{~m}$ a.s.l. The reserve is situated in the zone of extremely continental climate, 24-hour amplitude fluctuations of temperature reach $15-20^{\circ} \mathrm{C}$, and year ones $-80{ }^{\circ} \mathrm{C}$. During dry years $150 \mathrm{~mm}$ precipitation fall, in wet years - up to $350 \mathrm{~mm}$. Cyclic changes in humidity with alternation of drought and wet periods about 30 years in duration are characterisric of Dauria [1].

The peculiar feature of the area's geographic location is its position at the junction of two steppe provinces - Mongolian steppe and Hangai Daurian forest-steppe. The border

\footnotetext{
*Corresponding author: $\underline{\text { bagul72@mail.ru }}$
} 
position of the reserved area at the junction of two provinces determines the mixed character of the flora with combination of various elements.



Fig. 1. Location of Daursky reserve and its clusters

In 1986 while the reserve was being founded B.I. Dulepova compiled the first floristic list, which included 124 species of higher vascular plants. Goal-oriented investigations of the flora and vegetation started from August 1994 and have been going on up to now. The author of this article made the first herbarium collections in the floodplain of the Imalka river (station Bolotovo) in Imalkinsky sector, conducted the first geobotanical descriptions, laid monitoring plots and profiles. These collections were put in the basis of creating the Daursky reserve's Herbarium. From 1995 to 2020 joint investigations were held with specialists of the following scientific research and educational institutions: Central Siberian Botanic Garden / CSBG, Siberian Branch of the Russian Academy of Sciences / SB RAS (Novosibirsk); Botanic Institute / BI of the RAS (Saint Petersburg); Zabaikalsky Botanic Garden; Transbaikal State University / TSU; University of Kassel (Germany); Biological Soil Institute - Far-Eastern Branch / FEB of the RAS (Vladivostok); Irkutsk State University / ISU (Irkutsk); Siberian Institute of Plant Physiology and Biochemistry / SIPPhB, SB RAS (Irkutsk). The purpose of the work is to sum up multi-year data and to identify the species composition, to analyze taxonomic structure of the flora in the Daursky reserve. The conducted expeditions and original author's materials have enabled to get new data about the floristic richness of the studied area, to extend the list and the collection materials of the Herbarium of the Federal State Budget Institution, State Nature Biosphere Reserve "Daursky".

\section{Materials and methods}

The materials for the article are multi-year (1994 to 2020) herbarium collections kept in the Herbarium of the Federal State Budget Institution, State Nature Biosphere Reserve "Daursky" and author's geobotanic materials, geobotanic decriptions from the collection 
«Database of Siberian Vegetation (DSV)» of the international metabase of phytocenotecks «Global Index of Vegetation-Plot Databases» under the index AS-RU-002 [2]. In the work the collections of the following collectors were considered: A.Yu. Korolyuk, E.A. Korolyuk, V.A. Cheremushkina, M.N. Lomonosova, N.I. Makunina, S.V. Ovchinnikova, T.V. Maltseva, V.M. Doronkin, N.K. Kovtonyuk, I.V. Han, N.A. Dulepova (CSBG of SB RAS, Novosibirsk); A.K. Sytin, T.V. Krestovskaya (BI of RAS, Saint Petersburg); O.V. Sidneva, E.M. Shipulina (Zabaikalsky Botanic Garden); H. Freitag and P. Schutze (Kassel, Germany); A.E. Kozhevnikova (FEB of RAS); V.V. Chepinoga (ISU, Irkutsk); S.G. Kazanovsky (SIPPhB, SB RAS, Irkutsk); herbariums of the country (LE, NS and NSK, TK, IRKU, IRK, TSU, Zabaikalsky Botanic Garden) and literature data [3, 4]. Taxonomic analysis of the reserve's flora is made on the basis of methods of comparative floristics [5]. Field research was conducted with route method. Geobotanic descriptions are made with standard methodology on plots of 100 sq.m [6].

\section{Results and discussion}

Flora of vascular plants in the Daursky reserve amounts to 634 species and sunspecies of vascular plants (including 604 aboriginal and 30 adventive ones) belonging to 74 families and 290 genera. Flora of Zabaikalsky krai consists of 1,700 species of vascular plants [7], where $37 \%$ of the total number are occupied by the flora of the Daursky reserve. High level of floristic diversity in the reserve confirms representativeness and a special natureprotecting significance of the area. Within the reserve's flora two florogenetic associations of elements are identified: aboriginal and adventive fractions of flora. Aboriginal (local) species are the species whose presence in the reserved area is bound to the history of species formation in the course of natural process of florogenesis development. Adventive species are those, which appeared in the area as a result of human activity, by introducing new species from outside, their dissemination or invasive plants turning wild. The element of adventives flora in the reserve is identified according to literature sources and the author's data $[8,9]$. Identification and analysis of aboriginal fraction enable to analyze the history of flora development, and of adventive one - the influence of anthropogenic transformation on the flora structure.

Aboriginal fraction of the reserve's flora includes 608 species and subspecies of 290 genera and 74 families. For one family there are on average two genera and eight families. The most widely represented is the group Magnoliophyta that comprises 592 aboriginal species or $97 \%$ of the total number of the reserve's flora. The least numerous groups are Polypodiophyta, Equisetophyta, Pinaphyta, they include 16 species or $3 \%$ of the total number of aboriginal species of the Daursky reserve's flora.

The analysis of family and species diversity of the reserve's flora showed that in the head parts of the spectre (1-5 rang) steadily located are the families: Asteraceae (83 species or $17 \%$ of the total number of aboriginal species), Poaceae (65 species or $14 \%$ ), Fabaceae (42 species or 9\%), Rosaceae (38 species or 8\%), Cyperaceae (30 species or 6\%) (table 1). In the families the average number of aboriginal species is 21 , absolute number -22 . The first ten families include 366 species of aboriginal species of flora, which is $77 \%$ of the total number. This indicator is very informative - if it exceeds $60 \%$, it characterizes the flora under analysis as boreal [10]. Nine families contain 10 to 23 species, 5 families -7 to 9 species, 36 families -2 to 8 species. 21 families are single-species ( $28 \%$ of the total number of families).

Ten leading genera of the reserve's flora span 118 aboriginal species of flora or $25 \%$ of aboriginal fraction of the flora, $30 \%$ of absolute number and $20 \%$ of the total number of flora richness in Zabaikalsky krai (table 2) [10]. The most diversity of species among flora genera of reserve is registered in the genus Carex (24 species), Artemisia (22), Potentilla 
(13), which makes $50 \%$ from 10 genera of native flora. In 4 genera - Potentilla, Oxytropis, Chenopodium, Allium 10 to 13 species are registered, in 5 genera - Allium, Astragalus, Poa, Iris, Calamagrostis 6 to 9 species, in 13 genera 4 to 5 species, in 99 genera 2 to 3 species. Single-species genera are represented by 175 genera in the reserve's flora $(59.5 \%$ of total number of aboriginal fraction genera).

Table.1. Family and species spectre of aboriginal flora of Daursky reserve

\begin{tabular}{|c|l|c|c|c|c|}
\hline \multirow{2}{*}{ № } & \multirow{2}{*}{ Families } & \multicolumn{3}{|c|}{ Composition of flora of Daursky reserve } \\
\cline { 3 - 6 } & & \multicolumn{2}{|c|}{$\begin{array}{c}\text { Aboriginal species } \\
\text { Absolute number of } \\
\text { species }\end{array}$} \\
\cline { 3 - 6 } & $\begin{array}{c}\text { Number of } \\
\text { species }\end{array}$ & Rang & $\begin{array}{c}\text { Number } \\
\text { of species }\end{array}$ & Rang \\
\hline 1. & Asteraceae & 83 & 1 & 84 & 1 \\
\hline 2. & Poaceae & 65 & 2 & 70 & 2 \\
\hline 3. & Fabaceae & 42 & 3 & 43 & 3 \\
\hline 4. & Rosaceae & 38 & 4 & 41 & 4 \\
\hline 5. & Cyperaceae & 30 & 5 & 30 & 6 \\
\hline 6. & Chenopodiaceae & 25 & 6 & 33 & 5 \\
\hline 7. & Ranunculaceae & 22 & $7-8$ & 22 & $7-8$ \\
\hline 8. & Brassicaceae & 22 & $7-8$ & 23 & $7-8$ \\
\hline 9. & Lamiaceae & 21 & 9 & 21 & 9 \\
\hline 10. & Scrophulariaceae & 18 & $10-11$ & 18 & $10-11$ \\
\hline Total & & $\mathbf{3 6 6}$ & & $\mathbf{3 8 5}$ & \\
\hline
\end{tabular}

Table. 2. Genera and species spectre of aboriginal flora of Daursky reserve

\begin{tabular}{|c|c|c|c|c|c|c|c|}
\hline \multirow{3}{*}{ № } & \multirow{3}{*}{ Genera } & \multicolumn{4}{|c|}{ Composition of genera in reserve's flora } & \multirow{2}{*}{\multicolumn{2}{|c|}{\begin{tabular}{|c|}
$\begin{array}{c}\text { Composition of } \\
\text { genera in flora of } \\
\text { Zabaikalsky kra }\end{array}$ \\
$\begin{array}{c}\text { Absolute number } \\
\text { of genera }\end{array}$ \\
\end{tabular}}} \\
\hline & & \multicolumn{2}{|c|}{ Aboriginal genera } & \multicolumn{2}{|c|}{$\begin{array}{c}\text { Absolute number of } \\
\text { genera }\end{array}$} & & \\
\hline & & \begin{tabular}{|c|} 
Number \\
of \\
species
\end{tabular} & Rang & $\begin{array}{c}\text { Number } \\
\text { of species }\end{array}$ & Rang & $\begin{array}{c}\text { Number } \\
\text { of species }\end{array}$ & Rang \\
\hline 1. & Carex & 24 & 1 & 24 & 1 & 111 & 1 \\
\hline 2. & Artemisia & 22 & 2 & 22 & 2 & 37 & $2-3$ \\
\hline 3. & Potentilla & 13 & 3 & 14 & 3 & 32 & 4 \\
\hline 4. & Oxytropis & 11 & 4 & 11 & $4-5$ & 26 & 5 \\
\hline 5. & Allium & 10 & 5 & 10 & 6 & - & - \\
\hline 6. & Astragalus & 9 & $6-7$ & 9 & $7-8$ & 19 & $8-9$ \\
\hline 7. & Poa & 9 & $6-7$ & 9 & $7-8$ & 21 & 7 \\
\hline 8. & Chenopodium & 8 & 8 & 10 & $4-5$ & - & - \\
\hline 9. & Iris & 6 & $9-11$ & 6 & 9 & - & - \\
\hline 10. & Saussurea & 6 & 9-11 & 6 & $10-11$ & 19 & $8-9$ \\
\hline & Total & 149 & 16 & 151 & 18 & 416 & 15 \\
\hline
\end{tabular}

Adventive fraction of the reserve's flora amounts to 30 species of 20 genera and 15 families, which is $5 \%$ of the species composition of vascular plants. Mostly on the territory of the reserve adventives species are bound to disturbed habitats: fallows, protective belts, roads, paths, pastures of livestock in the buffer zone of the reserve. The largest number of adventive genera and species are in the families: Chenopodiaceae ( 3 genera and 7 species) and Poaceae (3 genera and 5 species). Among adventive families are identified Urticaceae (2 species) and Boraginaceae (3 species) containing 1 genus and 2-3 species. All the other families Ulmaceae, Cannabaceae, Geraniaceae, Apiaceae, Solanaceae, Rubiaceae, Asteraceae contain one genus and species each. 
In the flora of the Daursky reserve 28 rare vascular plants are identified, which are included in the Red Book of the RF (2008) and the Red Book of Zabaikalsky krai (2017) $[7,11]$. Of 150 species of vascular plants in the Red Book of Zabaikalsky krai $19 \%$ of the total number are occupied by rare species of flora from the Daursky reserve.

So, the analysis of taxonomic structure of the vascular plants flora has shown that the flora of vascular plants includes 608 species and subspecies of vascular plants belonging to 74 families and 290 genera. The composition of the reserve's flora has two florogenetic associations of elements: aboriginal and adventives fractions. Aboriginal fraction of the reserve comprises 604 species subspecies of 290 genera and 74 families. The most widely represented is the group Magnoliophyta amounting to 592 aboriginal species or $97 \%$ of the total number of the reserve's flora. The least numerous groups are Polypodiophyta, Equisetophyta, Pinaphyta, which include 16 species or $3 \%$ of the total number. The spectre of the leading families of the reserve's flora is quite typical for boreal floras where the leading part is characteristic of the families: Asteraceae, Poaceae, Fabaceae, Rosaceae, Cyperaceae. Ten leading genera of the reserve's flora span 118 aboriginal species of flora, or $20 \%$ of aboriginal fraction. The most species diversity $50 \%$ of the whole number of aboriginal genera is occupied by the genera Carex, Artemisia, Potentilla. Adventive fraction is represented by 30 species of 20 genera and 15 families, which makes totally $5 \%$ of the total number of species, and is characterized by little anthropogenic transformation. Geographical position at the junction of provinces, variety of ecological conditions, preservation of ecosystems have determined on the relatively small reserved territory $(2 \%$ of Zabaikalsky krai area) high concentration and richness of flora (37\% of the total number of Zabaikalsky krai flora). Representativeness and floristic diversity of the Daursky reserve in the flora of Zabaikalsky krai rank the area as having a high level of biological diversity and a special nature-protecting value and significance.

\section{References}

1. V. Kirilyuk, T. Tkachuk, O. Kirilyuk, Problems of adaptation to climate in Dauria river basins: ecological and hydroeconomic aspects 5 (2012)

2. A. Yu. Korolyuk, A. A. Zverev, Database of Siberian Vegetation (DSV) Biodiversity \& Ecology 4 (4) (2012)

3. L. I. Saraeva, S. V. Goryunova, Botanic research in the Daursky reserve. IV (Chita, Poisk, 2007)

4. L. I. Saraeva, A. Yu. Korolyuk, N. A. Dulepova, Bulletin of ZSU. Natural Sciences, 1 (36) (2011).

5. A. I. Tolmachev, Methods of Comparative Floristics and Issues of Florogenesis (Novosibirsk, 1986)

6. E. M. Lavrenko, A. A. Korchagin Field geobotany 3 (M-L, 1964)

7. Red Book of the Trans-Baikal Territory. Plants (Novosibirsk, House of the World, 2017)

8. A. L. Abel, T. Yu. Strelnikova, A. N. Kupriyanov, O. A. Anenkhonov, E. S. Ankipovich, E. N. Antipova, A. V. Verkhozina, A. N. Efremov, Yu. A. Zykova, Bul. Princ. Bot. garden. 1 (2014)

9. N. M. Pazdnikova, V. V. Chepinoga, Ecology. 6 (1) (2013)

10. B. I. Dulepova, Plant world of Zabaikalye, Encyclopaedia of Zabaikalye, (http: ez.chita.ru/encycl/person/?id=2161 date of the application 15.06.2021)

11. The Red Book of the Russian Federation (plants and fungi) (2008) 